\title{
Assessing the Effect of Geotextile Mulch on Yield and Physico-Chemical Qualities of Litchi - A New Technical Approach
}

\author{
Tapas Sarkar, Tamanna Perween* and Pallab Datta
}

Department of Fruit Science, Bidhan Chandra Krishi Viswavidyalaya, Mohanpur, Nadia, West Bengal - 741252, India

*Corresponding author

\section{A B S T R A C T}

Keywords

Fruit quality, Geotextile mulch, Litchi, Moisture conservation, Yield

Article Info

Accepted:

15 June 2019

Available Online:

10 July 2019
Litchi is native to Southeast Asia and has been a favourite fruit of the world civilization since ancient times. The fruit is usually eaten fresh but can also be canned or dried. Geotextiles having potential for soil conservation, yield and physico-chemical improvement. Limited information is available to assess the effects of geotextiles in these aspects. The objective of this research was to analyze the effect of geotextile mulch on yield and quality of litchi. In the present study four treatments were taken viz., 500 GSM $\left(\mathrm{T}_{1}\right), 800 \mathrm{GSM}\left(\mathrm{T}_{2}\right), 1000 \mathrm{GSM}$ $\left(\mathrm{T}_{3}\right)$ geotextiles and control $\left(\mathrm{T}_{4}\right)$ plot. Result revealed that maximum panicle length $(36.18 \mathrm{~cm})$, fruit retention $(13.37 \%)$ and soil moisture $(13.95 \%)$ were recorded from mulching with $800 \mathrm{GSM}$ geotextile mulch. Maximum fruit length $(3.68 \mathrm{~cm}$.), fruit diameter $(3.37 \mathrm{~cm})$ and pulp weight $(13.16 \mathrm{~g})$ were recorded from mulching with 800 GSM geotextile followed by 1000 GSM geotextile mulch while the highest fruit weight $(24.19 \mathrm{~g})$ was obtained with $\mathrm{T}_{3}(1000 \mathrm{GSM})$ followed by $\mathrm{T}_{2}(800 \mathrm{GSM})$ and $\mathrm{T}_{1}(500 \mathrm{GSM})$. The highest yield $(91.79 \mathrm{~kg} / \mathrm{plant})$, anthocyanin content $(23.05 \mathrm{mg} / 100 \mathrm{~g})$, TSS $\left(19.83^{\circ} \mathrm{brix}\right)$, Total sugar $(13.91 \%)$ and TSS: acid ratio of 31.09 were also recorded under 800 GSM geotextile mulch.

\section{Introduction}

Litchi fruit belongs to genus Litchi from soapberry family, sapindaceae is believed to have originated in China. It is highly specific to climatic requirements and probably due to this reason its cultivation is restricted to few countries in the world. Litchi contains good amount of fiber which increase metabolism fat, protein and carbohydrate. Fiber rich foods have proved to suppress appetite and increase metabolism. Geotextiles or Textile mulches are permeable fabrics made from polypropylene or bio-degradable materials like jute and other fabrics. Geo-textile fabrics come in three basic forms: woven (resembling mail bag sacking), needle punched, or heat bonded. The main benefits of the geo-textile materials are to maintain biodiversity, conserve soil moisture (improve infiltration, reduce runoff, reduce evaporation), reduce soil erosion, moderate soil temperatures, suppress 
weeds and increase soil organic matter (organic and living mulches). Increased soil organic matter, in turn, has other beneficial effects, including improved soil structure, increased soil microbial activity (which suppresses soil-borne diseases) and additional slow-release of nutrients. Textile mulching is a technique used to prevent loss of soil moisture and promotes seedling establishment (Bu et al., 2013) mainly by reducing the soil surface exposure to direct solar radiation and by acting as insulation. This is particularly important in dry lands, where drought is frequent. The mulches have an effect on controlling the diurnal/seasonal fluctuation in soil temperature by increasing soil temperature during morning/winter and reducing it during midday or summer which has great importance in fruit crops regarding all aspects mentioned above. Many researchers found that mulched trees grow $67 \%$ better than that grows on bare soil. The effect of geotextile mulches on fruit is not known and its potential is also not exploited till date. Keeping this, the present investigation was undertaken.

\section{Materials and Methods}

The experiment was conducted on 12years old orchard on at Central Research Farm. Gayespur, BCKV during the year 2016- 2017. It comes under New alluvial zone, $\left(22^{0} 95\right.$ north latitude and $88^{0} 49$ east longitude). These place receive average annual rainfall of 1300$1500 \mathrm{~mm}$ with average maximum and minimum temperature of $38^{\circ} \mathrm{C}$ and $10^{\circ} \mathrm{C}$. The soil at the experimental field was Gangetic alluvial with sandy clay loam texture, good water holding capacity, well drained with moderate soil fertility status and soil $\mathrm{pH}$ of 6.9. Cultivars Bombai was taken for study. Experimental plot was laid out in RBD design having four treatments with four replication. Four treatments included three non-woven jute geotextiles viz., 500 GSM $\left(\mathrm{T}_{1}\right), 800 \mathrm{GSM}\left(\mathrm{T}_{2}\right)$,
$1000 \mathrm{GSM}\left(\mathrm{T}_{3}\right)$ and $0 \mathrm{GSM}\left(\mathrm{T}_{4}\right)$ or control plot.

The observations were recorded on five randomly selected plants from each plot on different growth, yield and quality parameters. The total number of fruits produced per plant was weighed and expressed in $\mathrm{Kg}$.

\section{Results and Discussion}

\section{Effect of geotextile mulch on panicle length, initial fruits set and final fruit retention}

Data presented on table 1 show that panicle length, initial fruits set and final fruit retention of the plant and soil moisture content increased by applying different geotextile mulches over control plants. Maximum panicle length $(36.18 \mathrm{~cm})$, final fruit retention $(13.37 \%)$ and soil moisture $(13.95 \%)$ were recorded from mulching with 800 GSM geotextile mulch (T2) followed by 1000 GSM geotextile mulch $\left(\mathrm{T}_{3}\right), 500$ GSM geotextile mulch $\left(\mathrm{T}_{1}\right)$. Such beneficial effect of mulching was also observed by Das et al., (2016) in litchi. Soil moisture content at 30-60 cm depth also improved by different level of geotextile mulch from plant with no mulch but not definite mean difference were observed among the different level (500, 800, 1000 GSM) of geotextile mulch used. Among them $\mathrm{T}_{2}$ (800 GSM) exhibited highest $(13.95 \%)$ soil moisture content followed by $\mathrm{T}_{3}(13.45 \%)$ and $\mathrm{T}_{1}(13.11 \%) . \mathrm{T}_{2}$ (1000 GSM) mulch showed maximum (74.91 number/panicle) initial fruit set followed by 800 GSM geotextile mulch $\left(\mathrm{T}_{2}\right)$ and 500 GSM geotextile mulch $\left(\mathrm{T}_{1}\right)$, while unmulched plants gave minimum values. Such an improvement in soil hydrothermal regime with mulching was also reported by Ghosh and Bauri (2003) and Dutta and Majumder (2009) in guava. Su et al., 2012 ground mulching effectively increased soil temperature and soil moisture. Bhattacharyya et al., (2010) also reported the effectiveness of 
geotextiles in reducing the soil and water loss. This might be due to the positive response of organic mulches on characteristics like panicle length, Initial fruit set and final fruit retention. Kumar et al., (2014) also observed the highest initial fruit set and fruit retention under the mulching treatment compared to nonmulching treatment in aonla.

\section{Effect of geotextile mulch on yield}

Fruit yield, fruit weight, fruit length, fruit diameter, pulp weight were also influenced by mulches. Significant improvement in fruit physical parameters (weight, length and diameter) of litchi fruit was also influenced significantly by application of various mulches as depicted in table 2. Maximum fruit length $(3.68 \mathrm{~cm}$.$) , fruit diameter (3.37 \mathrm{~cm})$ and pulp weight $(13.16 \mathrm{~g})$ were recorded from mulching with 800 GSM geotextile followed by 1000 GSM geotextile mulch but the highest fruit weight $(24.19 \mathrm{~g})$ was obtained with $\mathrm{T}_{3}$ (1000 GSM) followed by $T_{2}$ (800 GSM) and $\mathrm{T}_{1}$ (500 GSM). The fruit yield is an outcome of various biological interactions which involves morphological, physiological and biochemical changes that are taken place during the growth and development of a tree
(Donald, 1962). 800 GSM geotextile mulch resulted maximum yield $(91.79 \mathrm{~kg} / \mathrm{ha})$. This was due to increase in number of average pulp weight $(13.16 \mathrm{~g})$, fruit length and diameter $(3.68 \mathrm{~cm}$ and $3.37 \mathrm{~cm}$, respectively), and better plant growth in plants mulched with800 GSM geotextile. The increase in fruit yield might be due to conserving soil moisture, regulating temperature and suppressing weed growth. While the unmulched plants (Control) recorded the minimum yield $(87.08 \mathrm{~kg} / \mathrm{ha})$, fruit weight $(19.11 \mathrm{~g})$, minimum fruit length and breadth $(3.22 \mathrm{~cm}$ and $2.98 \mathrm{~cm})$. All characters have significant mean difference due varying mulching methods, except length and diameter of the fruit. The least in all respect was observed in control (unmulched) plants. Joshi et al., (2012) reported that use of mulch in litchi cv. Rose scented recorded a significant increase in plant height, plant spread and tree volume which could be ascribed to higher uptake of nutrients under mulch as it conserves soil moisture and moderates evaporation from soil surface. Many researchers have found in their experiment that yields increments of plants as a result of mulching with appropriate materials (Tilander and Bonzi, 1997).

Table.1 Effect of geotextile mulch on panicle length, initial fruit set, number of fruit /panicle and Soil moisture content

\begin{tabular}{|c|c|c|c|c|}
\hline Treatments & $\begin{array}{c}\text { Panicle length } \\
\text { (cm) }\end{array}$ & $\begin{array}{c}\text { Initial fruit set } \\
\text { (no./panicle) }\end{array}$ & $\begin{array}{c}\text { Final fruit } \\
\text { retention } \\
\text { (no./panicle) }\end{array}$ & $\begin{array}{c}\text { Soil moisture at } \\
\mathbf{3 0 - 6 0} \mathbf{\text { cm depth }} \\
(\mathbf{\%})\end{array}$ \\
\hline $\mathbf{T}_{\mathbf{1}} \mathbf{( 5 0 0}$ GSM) & $32.58 \mathrm{c}$ & $70.91 \mathrm{c}$ & $11.30 \mathrm{c}$ & $13.11 \mathrm{c}$ \\
\hline $\mathbf{T}_{\mathbf{2}}(\mathbf{8 0 0}$ GSM) & $36.18 \mathrm{a}$ & $73.88 \mathrm{~b}$ & $13.37 \mathrm{a}$ & $13.95 \mathrm{a}$ \\
\hline $\mathbf{T}_{\mathbf{3}}(\mathbf{1 0 0 0}$ GSM) & $35.84 \mathrm{~b}$ & $74.91 \mathrm{a}$ & $13.11 \mathrm{~b}$ & $13.45 \mathrm{~b}$ \\
\hline $\mathbf{T}_{\mathbf{4}}(\mathbf{c o n t r o l})$ & $27.30 \mathrm{~d}$ & $70.24 \mathrm{~d}$ & $9.74 \mathrm{~d}$ & $9.73 \mathrm{~d}$ \\
\hline $\mathbf{S . E m}(\mathbf{\pm})$ & 0.21 & 0.12 & 0.09 & 0.10 \\
\hline $\mathbf{C . D}(\mathbf{P = 0 . 0 5})$ & 0.66 & 0.37 & 0.29 & 0.31 \\
\hline
\end{tabular}

Similar letters denote homogeneous means with Duncan's test at 5\% 
Table.2 Effect of geotextile mulch on yield and physical quality characteristics of litchi fruit

\begin{tabular}{|c|c|c|c|c|c|}
\hline Treatments & $\begin{array}{c}\text { Fruit weight } \\
\text { (gm) }\end{array}$ & $\begin{array}{c}\text { Fruit length } \\
\text { (cm) }\end{array}$ & $\begin{array}{c}\text { Fruit } \\
\text { diameter }(\mathbf{c m})\end{array}$ & $\begin{array}{c}\text { Pulp wt. } \\
\text { (g) }\end{array}$ & $\begin{array}{c}\text { Yield } \\
\text { (Kg/plant) }\end{array}$ \\
\hline $\mathbf{T}_{\mathbf{1}}(\mathbf{5 0 0}$ GSM) & $21.05 \mathrm{c}$ & $3.26 \mathrm{c}$ & $3.18 \mathrm{c}$ & $12.79 \mathrm{c}$ & $90.37 \mathrm{c}$ \\
\hline $\mathbf{T}_{\mathbf{2}}(\mathbf{8 0 0} \mathbf{G S M})$ & $23.83 \mathrm{~b}$ & $3.68 \mathrm{a}$ & $3.37 \mathrm{a}$ & $13.16 \mathrm{a}$ & $91.79 \mathrm{a}$ \\
\hline $\mathbf{T}_{\mathbf{3}}(\mathbf{1 0 0 0} \mathbf{G S M})$ & $24.19 \mathrm{a}$ & $3.41 \mathrm{~b}$ & $3.30 \mathrm{~b}$ & $12.99 \mathrm{~b}$ & $91.58 \mathrm{~b}$ \\
\hline $\mathbf{T}_{\mathbf{4}}(\mathbf{c o n t r o l})$ & $19.11 \mathrm{~d}$ & $3.22 \mathrm{~d}$ & $2.98 \mathrm{~d}$ & $11.09 \mathrm{~d}$ & $87.08 \mathrm{~d}$ \\
\hline S.Em $\mathbf{(} \mathbf{(})$ & 0.17 & 0.04 & 0.03 & 0.11 & 0.65 \\
\hline C.D $(\mathbf{P}=\mathbf{0 . 0 5})$ & 0.53 & 0.12 & 0.08 & 0.33 & 2.03 \\
\hline
\end{tabular}

Similar letters denote homogeneous means with Duncan's test at 5\%

Table.3 Biochemical composition of litchi fruits as influenced by geotextile mulch

\begin{tabular}{|c|c|c|c|c|c|}
\hline Treatments & $\begin{array}{l}\text { Anthocyanin } \\
\text { content } \\
\text { (mg/100g) }\end{array}$ & $\begin{array}{c}\text { TSS } \\
\left({ }^{\mathbf{0}} \text { brix }\right)\end{array}$ & $\begin{array}{c}\text { Total sugar } \\
(\%)\end{array}$ & $\begin{array}{c}\text { Acidity } \\
(\%)\end{array}$ & $\begin{array}{l}\text { TSS Acid } \\
\text { ratio }\end{array}$ \\
\hline$T_{1}(500$ GSM $)$ & $20.11 \mathrm{c}$ & $19.12 \mathrm{c}$ & $13.76 \mathrm{c}$ & $0.69 \mathrm{~b}$ & $27.57 \mathrm{c}$ \\
\hline$T_{2}(800$ GSM) & $23.05 \mathrm{a}$ & $19.83 \mathrm{a}$ & $13.91 \mathrm{a}$ & $0.64 \mathrm{~cd}$ & $31.09 \mathrm{a}$ \\
\hline $\mathrm{T}_{3}(1000 \mathrm{GSM})$ & $22.98 \mathrm{~b}$ & $19.71 \mathrm{~b}$ & $13.84 \mathrm{~b}$ & $0.64 \mathrm{~cd}$ & $30.91 \mathrm{~b}$ \\
\hline $\mathbf{T}_{4}$ (control) & $18.79 \mathrm{~d}$ & $17.99 \mathrm{~d}$ & $11.47 \mathrm{~d}$ & $0.83 \mathrm{a}$ & $21.58 \mathrm{~d}$ \\
\hline S.Em ( $( \pm)$ & 0.17 & 0.15 & 0.106 & 0.01 & 0.28 \\
\hline C.D $(P=0.05)$ & 0.52 & 0.48 & 0.329 & 0.03 & 0.88 \\
\hline
\end{tabular}

Similar letters denote homogeneous means with Duncan's test at 5\%

Table.4 Effect of geotextile mulch on leaf nutrients content N, P and K

\begin{tabular}{|c|c|c|c|}
\hline Treatments & $\begin{array}{c}\text { Nitrogen } \\
\text { (\% dry wt.) }\end{array}$ & $\begin{array}{c}\text { Phosphorus } \\
\text { (\% dry wt.) }\end{array}$ & $\begin{array}{c}\text { Potassium } \\
\text { (\% dry wt.) }\end{array}$ \\
\hline $\mathbf{T}_{\mathbf{1}}(\mathbf{5 0 0}$ GSM) & $1.82 \mathrm{c}$ & $0.27 \mathrm{c}$ & $0.77 \mathrm{c}$ \\
\hline $\mathbf{T}_{\mathbf{2}}(\mathbf{8 0 0} \mathbf{G S M )}$ & $1.88 \mathrm{ab}$ & $0.30 \mathrm{a}$ & $0.86 \mathrm{ab}$ \\
\hline $\mathbf{T}_{\mathbf{3}}(\mathbf{1 0 0 0}$ GSM) & $1.88 \mathrm{ab}$ & $0.29 \mathrm{~b}$ & $0.86 \mathrm{ab}$ \\
\hline $\mathbf{T}_{\mathbf{4}}(\mathbf{c o n t r o l})$ & $1.73 \mathrm{~d}$ & $0.21 \mathrm{~d}$ & $0.70 \mathrm{~d}$ \\
\hline C.D $(\mathbf{P}=\mathbf{0 . 0 5})$ & 0.06 & 0.01 & 0.03 \\
\hline S.Em $\mathbf{(})$ & 0.02 & 0.00 & 0.01 \\
\hline
\end{tabular}

Similar letters denote homogeneous means with Duncan's test at 5\%

\section{Effect of geotextile mulch on fruit quality}

Fruit quality of litchi was also influenced significantly by the application of various intensity of the geotextile mulches (Table 3). The highest anthocyanin content (23.05 $\mathrm{mg} / 100 \mathrm{~g})$, TSS (19.83 ${ }^{\circ}$ brix $)$, total sugar $(13.91 \%)$ and TSS: acid ratio of 31.09 were recorded under 800 GSM geotextile mulch followed by 1000 GSM geotextile mulch while control registered the minimum. Mulching ensured higher values of soil moisture as a result of reducing water evaporation from the soil surface. The changes occurred in the soil water regime had an obvious effect on fruit quality. Thus, soil 
maintenance systems by mulching might have a positive influence on the TSS. The unmulched plants (control) recorded the minimum TSS $\left(18.79^{\circ}\right.$ Brix). Similar findings were obtained by Mal et al., (2006) who reported that higher TSS is related to weed free environment, higher moisture conservation and maximum nutrient uptake under mulch condition in pomegranate. The decrease in acidity under 800 geotextile mulching $(0.64 \%)$ was due to increase in TSS and Sugar/acid ratio which resulted in good quality fruits. Acidity was maximum in control $(0.83 \%)$ fruits. Monteiro and Lopes (2007) also opined that cover crops decreased total acidity content of vine as compared with soil tillage and increased the soluble sugars, sugar to acid ratio in red grape varieties. Considerable decrease in the acidity during ripening of the fruit was due to their conversion into sugar. Acids could be considered as reserve source of energy to the fruit. The increase Sugar/acid ratio in 800 GSM mulching was due to increase in TSS content and reduction in acid content of the arils. Improvement in fruit quality in litchi due to the application of different intensity of geotextile mulch might be due to better soil moisture content and soil mineralization and also an increased rate of photosynthesis which cumulatively improved the fruit quality. Our results corroborate the results obtained by the Mahmoud and Sheren (2014) in pomegranate.

\section{Effect of geotextile mulch on leaf nutrient content}

Leaf mineral content ( $\mathrm{N}, \mathrm{P}$ and $\mathrm{K}$ ) was also influenced significantly by the application of different mulches. The 800 and 1000 GSM proved most effective and had the highest content of leaf mineral $(1.88 \% \mathrm{~N}$ and $0.86 \%$ $\mathrm{K})$ except phosphorus. Mulching with 800 GSM showed the maximum phosphorus content $(0.30 \%)$ of leaf followed by mulches with $1000 \mathrm{GSM}$. The least mineral content in all cases were recorded from unmulched (control) plot. The increased level of nitrogen due to geotextile mulching indicated that diffusion of nitrogen into the roots grown under the mulches was greater than unmulched plots (Table 4). The increased leaf nitrogen may also be ascribed to the high moisture regime observed under mulched plots, mitigating shrinkage of roots and soil solution (Kozlowski, 1972). Different mulches increased the phosphate content of leaves because surface soil was kept moist for a longer time. The highest potassium uptake under mulched plots may be due to presence of a higher moisture regime, maintenance of optimum level of soil temperature and a reduction in temperature fluctuation (Russell, 1975). Mulches from different organic materials with variable properties have different effects on the soil food web, as well as the mineralization of the elements such as $\mathrm{N}$ and $\mathrm{P}$ as reported by Forge et al., (2003). The results of our current study are also in close conformity with the earlier findings of Dutta and Majumder (2009) in guava.

The results demonstrated that application of geo-textile mulches was found promising for improving fruit yield and quality of litchi fruit along with the improvement in biological properties of orchard soil. From the course of study among the different mulches used, 800 GSM mulch was found to be most effective in improving the fruit physico-chemical, leaf mineral composition and biological attributes of soil. Therefore, this information can be transmitted to the litchi growers for commercial adoption. Geotextile jute mulches could be a viable eco-friendly technology for improving yield and quality of litchi orchards.

\section{References}

Bhattacharyya, R., Smets, T., Fullen, M. A., Poesen, J. and Booth, C.A. 2010 Effectiveness of geotextiles in reducing 
runoff and soil loss: A synthesis. CATENA81(3): 184-195.

Bu, L.D., Liu J.L., Zhu, L., Luo, S.S., Chen, X.P., Li, S.Q., Hill, R.L., Zhao, Y. 2013. The effects of mulching on maize growth, yield and water use in a semiarid region. Agric Water Manage. 123: 71-78.

Das, K. Sau, S. Sarkar, T. and Dutta, P. 2016. Effect of organic mulches on yield, physico-chemical qualities and leaf mineral composition of litchi cv. Bombai in Indo-Gangetic plain of West Bengal. Journal of Crop and Weed, 12(3): 67-69.

Dutta, P. and Majumder, D.2009. Effect of mulching on post-harvest quality of guava cv. L-49 grown in red and laterite tract of West Bengal. Adv. Hort. Sci., Italy. 23: 175-78.

Forge, T.A., Hugue E., Neilsen, G. and Neilsen, D. 2003. Effects of organic mulches on soil microfauna in the root zone of apple: implications for nutrient fluxes and functional diversity of soil food web. Appl. Soil Ecol., 22: 39-54.

Ghosh S.N. and Bauri F.K. 2003. Effect of mulching on yield and physic-chemical properties of mango fruit cv. Himsagar grown in rainfed laterite soil. The Orissa Journal of Horticulture. 31(1): 78-81.

Joshi, G., Singh, P. K., Srivastava, P.C. and Singh, S.K. 2012. Effect of mulching, drip irrigation scheduling and fertilizer levels on plant growth, fruit yield and quality of litchi (Litchi chinensis Sonn.).
Indian J. Soil Cons., 40(1): 46-51.

Kumar, V. 2014. Effect of different organic mulching materials on soil properties of 'NA 7' Aonla (Emblica officinalis) under rainfed condition of shiwalik foothills of Himalayas India. The Bioscaan. 9(1): 561-564

Mahmoud, I. E. D. and Sheren E. H.2014. Improving growth and productivity of pomegranate fruit trees planted on sandy dunes slopes at Baloza District (N. Sinai) using different methods of drip irrigation, organic fertilization and soil mulching. IOSR J. Agri. Vet. Sci., 7(12): 86-97.

Mal, B., Banik, B. C. Ghosh, S. N. and Maity, P. K. 2006. Studies on the effect of mulching in pomegranate cv. Ganesh. Proceedings of National symp. Prod. Util. and Export of UnderUtilized Fruits with Commercial Potentialities, held at Bidhan Chandra Krishi Vishwavidyalaya, West Bengal, November 22-24, pp. 163-167.

Monteiro, A. and Lopes, C. M. 2007. Influence of cover crop on water use and performance of vineyard in Mediterranean Portugal. Agric. Ecosyst. Environ.121: 336-342.

Russell, E.W.C. 1975. Soil Condition and Plant Growth. ELBS and Longman, $10^{\text {th }}$, U.K.

Tilander, Y. and Bonzi. M. 1997. Water and nutrient conservation through the use of agroforestry mulches, and sorghum yield response. Plant and Soil. 197: 219-232.

\section{How to cite this article:}

Tapas Sarkar, Tamanna Perween and Pallab Datta. 2019. Assessing the Effect of Geotextile Mulch on Yield and Physico-Chemical Qualities of Litchi - A New Technical Approach. Int.J.Curr.Microbiol.App.Sci. 8(07): 1984-1989. doi: https://doi.org/10.20546/ijcmas.2019.807.236 